\title{
RETROSPECTIVE ANALYSIS OF ALPHA GLOBIN COPY NUMBER VARIATIONS DETERMINED BY MLPA IN THE TRAKYA REGION
}

\author{
TRAKYA BÖLGESINDE MLPA ILE BELIRLENEN ALFA GLOBIN KOPYA SAYISI \\ DEĞIŞiKLIKLERININ RETROSPEKTIF ANALIZi
}

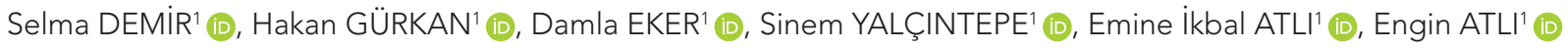 \\ ${ }^{1}$ Trakya University, Faculty of Medicine, Department of Medical Genetics, Edirne, Turkey
}

ORCID IDs of the authors: S.D.0000-0002-0964-5513; H.G.0000-0002-8967-6124; D.E.0000-0001-7563-118X;

S.Y.0000-0002-8557-8885; E.I.A.0000-0001-9003-1449; E.A.0000-0002-3937-5243

Cite this article as: Demir S, Gurkan H, Eker D, Yalcintepe S, Atli El, Atli E. Retrospective analysis of alpha globin copy number variations determined by mlpa in the Trakya region. J Ist Faculty Med 2021;84(3):348-53. doi: 10.26650/IUITFD.2021.880592

\begin{abstract}
Objective: Alpha thalassemia is a common type of hemoglobinopathy that occurs as a result of deletions or point mutations in the alpha globin gene cluster. The molecular analysis of alpha thalassemia is challenging due to the presence of genes with high sequence similarities in alpha globin gene clusters and pseudogenes. As well as in all genetic diseases, determining the causative mutation types of alpha thalassemia and their frequencies have critical importance for accurate genetic screening and prevention strategies.

Material and Method: In our study, alpha globin copy number variations determined by the Multiplex Ligation-dependent Probe Amplifcation (MLPA) method were examined retrospectively with suspicion of alpha thalassemia in 35 female and 43 male patients tested in the Genetic Diseases Diagnosis Center of the Medical Genetics Department at Trakya University Faculty of Medicine.
\end{abstract}

Results: The most common deletion among our patients was the $-\alpha^{3.7}(35.3 \%)$, followed by the $-\alpha^{20.5}(10.3 \%)$ deletion. The $-\alpha^{\text {SEA }}$ deletion was detected in three patients while 4 out of 78 cases were found to have the $-\alpha^{\text {MED }}$ deletion. In three patients, a heterozygous large deletion and in one case HS40 regulatory region deletion were detected. In 14 (18\%) of the patients, a globin triplications were detected. The $-\alpha^{4.2}$ deletion was detected in only one of our patients.

Conclusion: Our study is the first to report the presence of eight different alpha globin copy number changes and 13 different alpha globin genotypes in the Trakya region.

Keywords: Alpha thalassemia, globin, copy number variation

\section{ÖZET}

Amaç: Alfa talasemi, alfa globin gen kümesindeki delesyonların veya nokta mutasyonlarının bir sonucu olarak ortaya çıkan yaygın bir hemoglobinopati türüdür. Alfa talaseminin moleküler analizi, alfa globin gen kümesinde yüksek dizi benzerliklerine sahip genlerin ve psödogenlerin varlığı nedeniyle zordur. Tüm genetik hastalıklarda olduğu gibi, alfa talasemide de, altta yatan mutasyon türlerinin ve sıklıklarının belirlenmesi, doğru genetik tarama ve önleme stratejileri için kritik öneme sahiptir.

Gereç ve Yöntem: Çalışmamızda, alfa talasemi şüphesiyle Trakya Üniversitesi Tıp Fakültesi Tıbbi Genetik Anabilim Dalı Genetik Hastalıklar Tanı ve Değerlendirme Merkezinde test edilen 35 kadın ve 43 erkek hastada Multipleks Ligasyon-bağımlı Prob Amplifikasyon (MLPA) yöntemiyle belirlenen alfa globin kopya sayısı varyasyonları geriye dönük olarak incelendi.

Bulgular: Olgularımız arasında en sık $(\% 35,3)$ saptanan delesyon $-\alpha^{3.7}$ ve ardından \%10,3 görülme sıklığı ile $-\alpha^{20.5}$ delesyonu gelmekteydi. Üç olguda tüm probları kapsayan büyük delesyon, bir olguda ise HS40 düzenleyici bölgesinde delesyon saptanırken, 78 olgunun $4^{\prime}$ ünde $-\alpha^{\text {MED }}$, üçünde ise $-\alpha^{\text {SEA }}$ delesyonu saptandı. Olguların 14'ünde (\%18) $\alpha$ globin triplikasyonları belirlendi. $-\alpha^{4.2}$ delesyonu olgularımızdan yalnızca bir tanesinde saptandı.

Sonuç: Çalışmamız, Trakya bölgesinde sekiz farklı alfa globin kopya sayısı değişikliği ve 13 farklı alfa globin genotipinin varlığını bildiren ilk çalışmadır.

Anahtar Kelimeler: Alfa talasemi, globin, kopya sayısı değişikliği

Corresponding author/iletişim kurulacak yazar: selmademir1980@gmail.com

Submitted/Başvuru: 16.02.2021 • Revision Requested/Revizyon Talebi: 15.03.2021 •

Last Revision Received/Son Revizyon: 05.04.2021 • Accepted/Kabul: 06.04.2021 • Published Online/Online Yayın: 02.07.2021 


\section{INTRODUCTION}

Alpha thalassemia, a hematological disorder characterized by the lack or absence of alpha globin chain synthesis, is a common global hemoglobinopathies. The alpha globin (a-globin) gene cluster located in the subtelomeric region of the $16^{\text {th }}$ chromosome is responsible for the synthesis of the alpha globin chains, which are important components of the hemoglobin. This region consists of the HBZ (OMIM 142310), HBA2 (OMIM 141850), HBA1 (OMIM 141800) and HBQ1 (OMIM 142240) genes and is under the control of the $\mathrm{HS}-40$ regulatory region. Defects in the alpha globin genes in the same chromosome cause a mild phenotype resulting in either a silent alpha thalassemia or alpha thalassemia-trait phenotype, depending on the number of genes affected. $\mathrm{HbH}$ disease, on the other hand, is a severe form of alpha thalassemia due to the homozygous or compound heterozygous mutations of alpha globin genes. The severest form of alpha thalassemia is Hb Bart's hydrops fetalis syndrome, associated with total loss of alpha globin expression (1-3). Point mutations may cause a-thalassemia, but the most common cause is deletion of the genes located in the alpha globin cluster on one or both chromosomes (4).

Determining alpha globin mutations is of great importance in countries where consanguineous marriages are common, in order to prevent hydrops fetalis, the most severe form of the disease, and for accurate genetic counselling. There have been studies reporting the frequency and the underlying mutation types of alpha thalassemia in different regions of our country (4-13). However, to our knowledge, no study has reported the frequencies of copy number changes of the alpha globin cluster in the Trakya Region of Turkey.

In this study, we aimed to present the results of Multiplex Ligation-dependent Probe Amplification (MLPA) of patients whose genetic analyzes were performed with suspicion of alpha thalassemia in the Genetic Diseases Diagnosis Center of the Medical Genetics Department in Trakya University's Faculty of Medicine between November 2012 and September 2020.

\section{MATERIAL AND METHOD}

The results of alpha globin copy number variations of 78 patients (35 females, 43 males, mean age $23.80 \pm 22.4$ years) referred to our center with alpha thalassemia were included in this study. Ethics committee approval of the study was obtained with the approval of Trakya University Faculty of Medicine Scientific Research Ethics Committee (TUTF-BAEK 2020/380.). A written informed consent form was obtained from the patients or from the legal guardians of the younger cases.

Genomic DNA isolation was performed with the Qiagen EasyOne automatic DNA isolation system (Qiagen,
Hilden, Germany) from $2 \mathrm{ml}$ peripheral blood samples taken into an EDTA tube. Quality control and purity of the isolated genomic DNA samples were determined by NanoDrop spectrophotometrically [NanoDrop 2000C; Thermo Fisher Scientific Inc., Wilmington, MA, USA]. The MLPA method was applied to determine a-globin copy number variations in high quality samples with A260/280 values between 1.8-2.0.

The P140 HBA kit (MRC-Holland, Amsterdam, The Netherlands), including 45 probes designed to investigate alpha globin cluster copy number variations, was used for MLPA study. Fluorescent fragments obtained after ligation and amplification (performed in accordance with the manufacturer's protocol) were seperated on the ABI 3130 XL (Applied BioSystems, USA) capillary electrophoresis system and sizes of the fragments were determined using the GeneMapper (Applied BioSystems, USA) program. The results were analyzed with the Coffalyser software (MRC Holland). R open software was used to calculate the descriptive statistics (14).

\section{RESULTS}

The most common genotype among our cases was the $-a^{3.7} / \alpha \alpha$ genotype with a frequency of $46.20 \%$. The most common type of globin deletion was also the $-a^{3.7}$ deletion with $35.3 \%$. The second most common deletion was the $-a^{20.5}$ deletion detected in $10.3 \%$ of the cases. A large deletion covering all probes was detected in three cases, while a heterozygous deletion of the HS40 regulatory region was determined in only one patient. In 14 (18\%) of the cases, the a globin triplications were detected. The $-a^{4.2}$ deletion was detected in only one of our cases. Figure 1 presents Coffalyser views of the triplication, showing the $-a^{\text {MED }}$ and $-a^{20.5}$ deletions with the biallelic $-a^{3.7} /-a^{20.5}$ deletion. The genotypes and hematological parameters of the cases are shown in Table 1, and the distribution of globin variants of the cases among the total number of chromosomes is shown in Table 2.

\section{DISCUSSION}

Molecular analysis of alpha thalassemia is challenging due to the presence of four copy genes encoding alpha globin chains. Determination of regional mutation diversity is important to prevent alpha thalassemia, which has a wide phenotypic variety ranging from silent carriers to hydrops fetalis. In our study, 8 different alpha globin copy number changes were determined. Seven of them were deletions of different sizes of the alpha globin gene cluster and regulatory elements, and the remaining one copy number variation type was the $-a^{3.7}$ triplication.

$\mathrm{a}^{+}$thalassemia are caused by deletions or rare point mutations in one of the duplicated alpha globin genes. $-a^{3.7}$ or $-a^{4.2}$ deletions, resulting from unequal crossing 
Table 1: Genotypes of the patients and mean and standard deviation values of hematological parameters according to their genotypes

\begin{tabular}{|c|c|c|c|c|c|c|}
\hline Genotype & $\mathrm{n}$ & (\%) & $\begin{array}{c}\text { ES } \\
(4.63-6.08) \\
\end{array}$ & $\begin{array}{c}\text { Hemoglobin } \\
(13.7-17.5)(\mathrm{g} / \mathrm{dl})\end{array}$ & $\begin{array}{l}\text { Mean corpuscular } \\
\text { volume (79-92.2)(fl) }\end{array}$ & $\begin{array}{l}\text { Red cell distribution } \\
\text { width }(11.6-14.4)(\%)\end{array}$ \\
\hline$-a^{3.7} / a \alpha$ & 36 & 46.20 & $5.247 \pm 0.730$ & $12.088 \pm 2.212$ & $71.597 \pm 6.569$ & $17.253 \pm 7.357$ \\
\hline$-a^{3.7} /-a^{3.7}$ & 7 & 8.90 & $5.354 \pm 0.588$ & $11.371 \pm 1.619$ & $65.88 \pm 3.387$ & $15.642 \pm 1.081$ \\
\hline$-a^{20.5} / \alpha a$ & 8 & 10.30 & $5.366 \pm 0.339$ & $11.09 \pm 0.765$ & $64.175 \pm 5.912$ & $16.15 \pm 0.85$ \\
\hline$-a^{\mathrm{MED}} / \mathrm{aq}$ & 3 & 3.80 & $4.82 \pm 0.991$ & $9.8 \pm 2.389$ & $67.733 \pm 7.804$ & $20.33 \pm 8.220$ \\
\hline$-a^{3.7} /-a^{\text {SEA }}$ & 2 & 2.50 & $4.895 \pm 0.261$ & $8.835 \pm 0.09$ & $55.75 \pm 2.474$ & $21.95 \pm 4.03$ \\
\hline $\begin{array}{l}\text { Whole gene } \\
\text { deletion }\end{array}$ & 3 & 3.80 & $5.75 \pm 0.277$ & $12.066 \pm 0.288$ & $66.166 \pm 3.536$ & $15 \pm 1.014$ \\
\hline$\alpha_{a q} a^{a n t-3.7} / \alpha a$ & 13 & 16.70 & $5.1 \pm 0.611$ & $11.13 \pm 2.227$ & $66.753 \pm 10.809$ & $17.815 \pm 4.765$ \\
\hline $\begin{array}{l}\operatorname{aqq}^{\text {anti-3.7. / }} \\
\operatorname{aqd}^{\text {anti-3.7 }}\end{array}$ & 1 & 1.30 & 5.34 & 14.3 & 74.4 & 34.1 \\
\hline$-a^{\text {SEA }} / a \alpha$ & 1 & 1.30 & - & 12 & 68 & - \\
\hline$-a^{\mathrm{HS} 40} / \mathrm{aq}$ & 1 & 1.30 & 6.24 & 13.7 & 67.1 & 16.1 \\
\hline$-a^{3.7} /-a^{20.5}$ & 1 & 1.30 & 5.28 & 9.5 & 61.4 & 22.2 \\
\hline$-a^{3.7} /-a^{\mathrm{MED}}$ & 1 & 1.30 & 5.28 & 8.8 & 55.9 & 33.3 \\
\hline$-a^{3.7} /-a^{4.2}$ & 1 & 1.30 & 6.26 & 12.3 & 62.6 & 15 \\
\hline Total & 78 & 100 & & & & \\
\hline
\end{tabular}

Table 2: Distribution of alpha globin variants among the total number of chromosomes

\begin{tabular}{lcc}
\hline $\begin{array}{l}\text { Alpha globin } \\
\text { variant }\end{array}$ & $\begin{array}{c}\text { Affected chromosome } \\
\text { count }\end{array}$ & $\%$ \\
\hline aa (Normal) & 65 & 41.7 \\
$-\mathrm{a}^{3.7}$ & 55 & 35.3 \\
$-\mathrm{a}^{20.5}$ & 9 & 5.8 \\
$-\mathrm{MED}$ & 4 & 2.6 \\
aad $^{\text {anti-3.7 }}$ & 15 & 9.6 \\
$-\mathrm{a}^{\text {SEA }}$ & 3 & 1.9 \\
$-\mathrm{a}^{\text {HS40 }}$ & 1 & 0.6 \\
$-\mathrm{a}^{4.2}$ & 1 & 0.6 \\
Whole gene & 3 & 1.9 \\
deletion & & 100 \\
Total & 156 & \\
\hline
\end{tabular}

over in meiosis, causes deletional $a^{+}$thalassemias and the most common cause has been reported as the $-a^{3.7}$ deletion (3). The frequency of $-a^{3.7}$ deletions was reported as $52.28 \%$ in the study performed by Onay et al. in the Aegean Region of Turkey (4). In a study performed by Çelik et al. in the southern region of Turkey, $-a^{3.7}$ deletion frequency was reported as $43.2 \%$ (10). Karakaş et al. reported the frequency of $-a^{3.7}$ deletion as $39 \%$ in a study they performed on patients with hypochromic mi- crocytic anemia living in Istanbul (11). Our data are in accordance with the results of this study carried out in Istanbul, which is located close to the Trakya region. $-a^{4.2}$, another type of deletion underlying a+ thalassemias, is reported less frequently than the $-a^{3.7}$ deletion. Karakaş et al. reported the frequency of $-a^{4.2}$ deletion as $4.2 \%$, and Onay et al. reported that they did not detect any $-a^{4.2}$ deletion $(6,11)$. In our study, the $-a^{4.2}$ deletion was found in only one case as compound heterozygous with the $-a^{3.7}$ deletion.

The second most common deletion in our study was $-a^{20.5}$ with a ratio of $5.8 \%$. This mutation has been rarely reported in Asia, the Middle East, and in Arab countries, but it was reported to be the second most frequent deletion in the studies conducted by Onay and Çürük et al. $(4,6)$. The $-a^{20.5}$ deletion was followed by the $-a^{\text {MED }}$ and $-a^{\text {SEA }}$ deletions with a frequency of $2.6 \%$ and $1.9 \%$, respectively, in our study. In the Turkish population - SEA deletion was reported for the first time in the study of Onay et al. (4) and it was found as compound heterozygous with the $-a^{3.7}$ deletion in a patient in our study, too.

It is challenging to predict alpha globin genotypes based on hematological parameters, though some studies and reports have investigated this. Studies report that patients with two functional alpha globin genes have higher Mean Corpuscular Volume (MCV) values compared to patients with a defected alpha globin gene $(15,16)$. Guvenc et al. and Onay et al. reported that that MCV value 


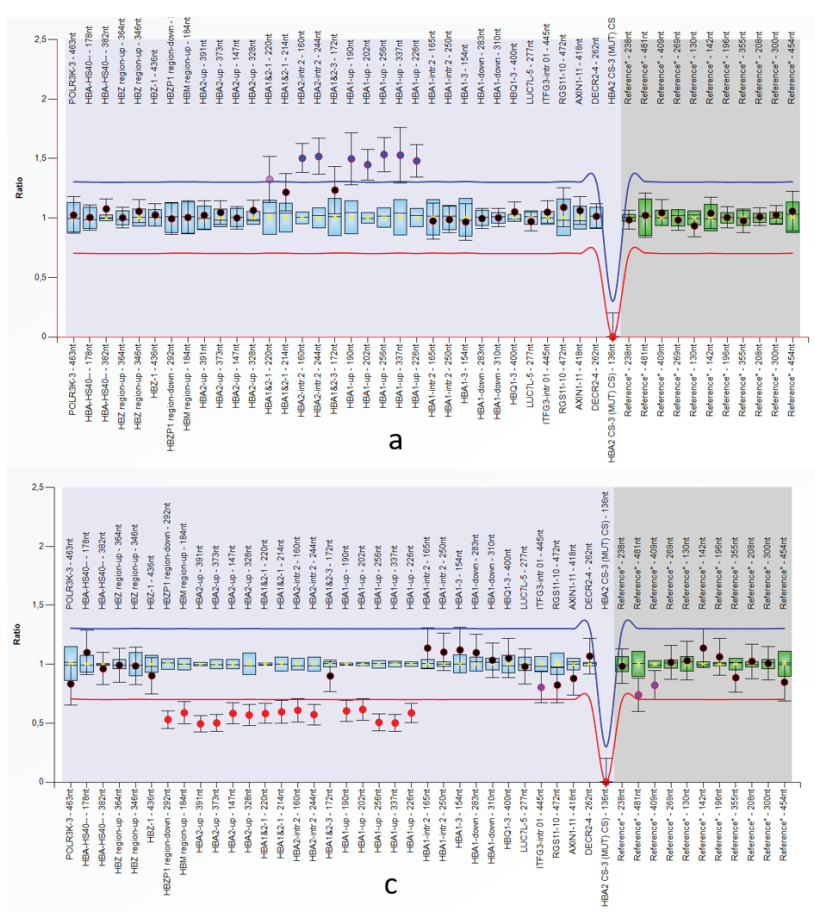

Figure 1: Coffalyser views of triplication (a); - $a^{\text {MED }}$ deletion

was the lowest for the genotype $-a^{3.7} /--a^{\text {MED }}$, and highest for the $-a^{3.7} / a a$ genotype in their studies $(6,9)$. Although the patient population is small for performing a statistical comparison, we also found that MCV values were lower in the patients with compound heterozygous $-a^{3.7 /}-a^{\text {MED }}$ ve $-a^{3.7 /}--a^{\text {SEA }}$ deletions compared to patients with $-a^{3.7 /}$ aa genotypes.

One of the common copy number changes of the alpha globin gene cluster is triplications (17). In our study, we found heterozygous triplications in 13 cases and homozygous aaa anti-3.7 triplication in one case. Although the thalassemic effect of these triplications is generally not expected, it is reported in the literature that when accompanied by beta globin gene (HBB) mutations, it can be an important modulator of the hemoglobinopathy phenotype (18-21). In our study, a pathogenic HBB variation was accompanied in $6 / 10$ of the cases with $-a^{3.7}$ triplication (data not shown), emphasizing the importance of these triplications in terms of genetic counseling of hemoglobinopathies.

Heterozygous HS-40 regulatory region deletion was determined in one of our patients with a mild anemia phenotype. Heterozygous deletion of the HS-40 regulatory region has been reported to reduce the a-globin expression. However, it was proposed that HS-40 regulatory region deletion can have a prominent down-regulatory effect which may reflect phenotypically if it is homozygous or in trans position with another deletion $(22,23)$.
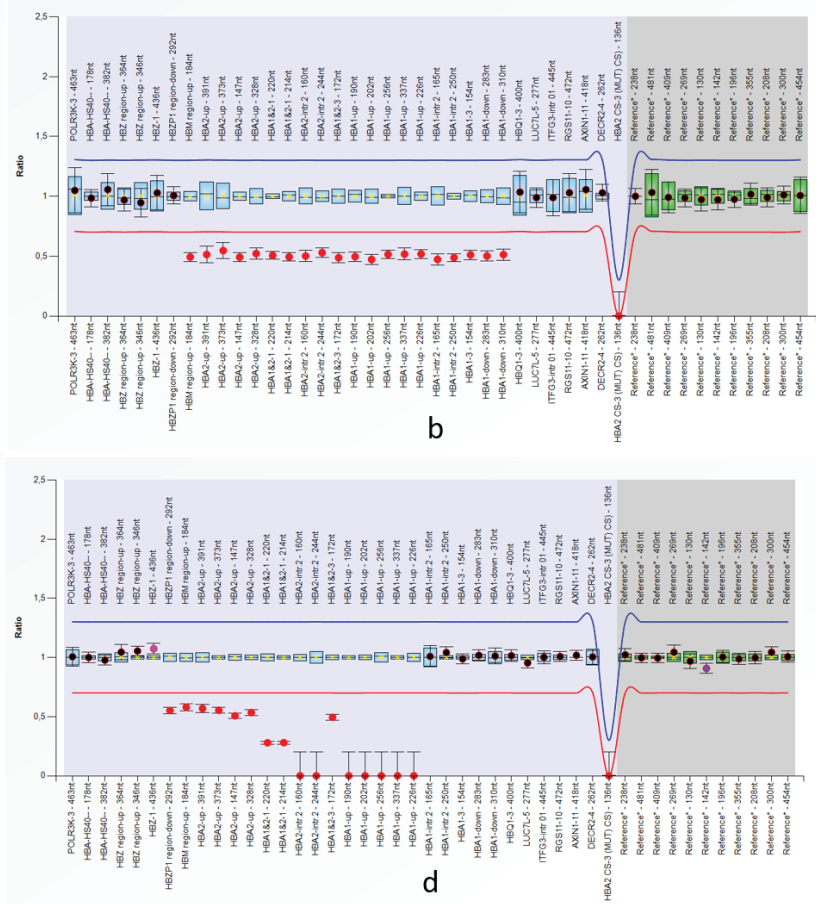

(b); $-a^{20.5}$ deletion (c); and biallelic $-a^{3.7} /-a^{20.5}$ deletion (d)

The deletion of the HS-40 regulatory site reduced the expression of HS-40 heterozygous deletion manifested as mild anemia, which was of the microcytic hypochromic type. When compounded with $-a^{3.7} / a a_{\text {, it }}$ manifested as $\mathrm{Hb} \mathrm{H}$ disease, and when compounded with -SEA/aa, it manifested as $\mathrm{Hb}$ Bart's fetus.

MLPA is a hybridization-based method that has been used for many years to screen deletions and duplications. For this reason, the MLPA method is often used to elucidate the genetic basis of alpha thalassemias (24). The advantages of the MLPA method over other methods in the genetic basis of alpha thalassemia have been reported in the studies of Yüreğir and Colosimo et al. $(13,25)$. However, other methods, such as reverse dot blot hybridization, are needed to detect non-deletion type mutations. Although it has been reported in studies conducted in Turkey and around the world that alpha globin mutations are mostly deletions, non-deletion type mutations are also encountered in some cases. Therefore, the limitation of this study is the inability to detect alpha thalassemias that are not deletion type.

In conclusion, our study is the first to show a high level of diversity of alpha globin gene copy number variations in the Trakya Region. In addition, it supports the findings of other studies that the MLPA method is useful for detecting copy number variations in the alpha globin cluster.

Ethics Committee Approval: This study was approved by the Scientific Research Ethical Committee of the Trakya University, Faculty of Medicine (TUTF-BAEK 2020/380). 
Informed Consent: Written consent was obtained from the participants.

Peer Review: Externally peer-reviewed.

Author Contributions: Conception/Design of Study- S.D., H.G.; Data Acquisition- S.D.,D.E., E.A.; Data Analysis/Interpretation- S.D., S.Y., E.I.A.; Drafting Manuscript- S.D., S.Y., E.I.A., E.A.; Critical Revision of Manuscript- H.K., M.Ö.; Final Approval and Accountability- S.D., D.E., H.G., S.Y., E.I.A., E.A.

Conflict of Interest: Authors declared no conflict of interest.

Financial Disclosure: Authors declared no financial support.

Etik Komite Onayı: Bu çalışma için etik komite onayı Trakya Üniversitesi, Tıp Fakültesi Bilimsel Araştırmalar Etik Kurulu'ndan alınmıştır (TUTF-BAEK 2020/380).

Bilgilendirilmiş Onam: Katılımcılardan bilgilendirilmiş onam alınmıştır.

Hakem Değerlendirmesi: Dış bağımsız.

Yazar Katkıları: Çalışma Konsepti/Tasarım- S.D., H.G.; Veri Toplama- S.D.,D.E., E.A.; Veri Analizi/Yorumlama- S.D., S.Y., E.I.A.; Yazı Taslağı- Y.K.; İçeriğin Eleştirel İncelemesi- S.D., S.Y., E.I.A., E.A.; Son Onay ve Sorumluluk- S.D., D.E., H.G., S.Y., E.I.A., E.A.

Çıkar Çatışması: Yazarlar çıkar çatışması beyan etmemişlerdir.

Finansal Destek: Yazarlar finansal destek beyan etmemişlerdir.

\section{REFERENCES}

1. Harteveld CL, Higgs DR. Alpha-thalassaemia. Orphanet J Rare Dis 2010;5:13. [CrossRef]

2. Patrinos GP, Kollia P, Papadakis MN. Molecular diagnosis of inherited disorders: lessons from hemoglobinopathies. Hum Mutat 2005;26(5):399-412. [CrossRef]

3. Farashi S, Harteveld CL. Molecular basis of a-thalassemia. Blood Cells Mol Dis 2018;70:43-53. [CrossRef]

4. Onay H, Aykut A, Karaca E, Durmaz A, Solmaz AE, Çoğulu Ö, et al. Molecular spectrum of a-globin gene mutations in the Aegean region of Turkey: first observation of three a-globin gene mutations in the Turkish population. Int $\mathrm{J}$ Hematol 2015;102(1):1-6. [CrossRef]

5. Canatan D, Oğuz N, Güvendik I, Yıldırım S. The Incidence of Alpha-Thalassemia in Antalya-Turkey. Turk J Haematol 2002;19:433-4.

6. Cürük MA. HbH (beta4) disease in Cukurova, Southern Turkey. Hemoglobin 2007;31:265-71. [CrossRef]

7. Basak AN. The molecular pathology of beta-thalassemia in Turkey: the Bogaziçi University experience. Hemoglobin 2007;31:233-41. [CrossRef]

8. Acemoglu H, Beyhun NE, Vancelik S, Polat $H$, Guraksin A. Thalassaemia screening in a non-prevalent region of a pre- valent country (Turkey): is it necessary? Public Health 2008;122(6):620-4. [CrossRef]

9. Guvenc B, Yildiz SM, Tekinturhan F, Dincer S, Akyuzluer I, Okten S, et al. Molecular characterization of alphaThalassemia in Adana, Turkey: A single center study. Acta Haematol 2010;123(4):197-200. [CrossRef]
10. Celik MM, Gunesacar R, Oktay G, Duran GG, Kaya H. Spectrum of a-thalassemia mutations including first observation of H.-(FIL) deletion in Hatay Province, Turkey Blood Cells Mol Dis 2013;51(1):27-30. [CrossRef]

11. Karakaş Z, Koç $B$, Temurhan S, Elgün T, Karaman S, Asker $G$, et al. Evaluation of alpha-thalassemia mutations in cases with hypochromic microcytic anemia: the Istanbul perspective. Turk J Haematol 2015;32(4):344-50. [CrossRef]

12. Ünal S, Oktay G, Acıpayam C, Illhan G, Gali E, Celkan T, et al. Hemoglobin $\mathrm{H}$ disease in Turkey: experience from eight centers. Turk J Haematol 2016;5;33(1):56-9. [CrossRef]

13. Yuregir OO, Ayaz A, Yalcintepe S, Canbek S, Acik DY, Yilmaz BT, et al. Detection of a-Thalassemia by Using Multiplex Ligation-Dependent Probe Amplification as an Additional Method for Rare Mutations in Southern Turkey. Indian J Hematol Blood Transfus 2016;32(4):454-59. [CrossRef]

14. Ihaka R, Gentleman R. R: A language for data analysis and graphics. J Comput Graph Stat 1996;5:299-314. [CrossRef]

15. Akhavan-Niaki $H$, Youssefi Kamangari R, Banihashemi A, Kholghi Oskooei V, Azizi M, Tamaddoni A, et al. Hematologic features of alpha thalassemia carriers. Int J Mol Cell Med 2012;1(3):162-7.

16. Velasco-Rodríguez D, Blas C, Alonso-Domínguez JM, Vega G, Soto C, García-Raso A, et al. Cut-Off values of hematologic parameters to predict the number of alpha genes deleted in subjects with deletional alpha thalassemia. Int J Mol Sci 2017;13;18(12):2707. [CrossRef]

17. Wu MY, Zhou JY, Li J, Li DZ. The Frequency of a-Globin Gene Triplication in a Southern Chinese Population. Indian J Hematol Blood Transfus 2016;32(Suppl 1):320-22. [CrossRef]

18. Ma SK, Au WY, Chan AY, Chan LC. Clinical phenotype of triplicated alpha-globin genes and heterozygosity for beta0-thalassemia in Chinese subjects. Int $\mathrm{J} \mathrm{Mol} \mathrm{Med}$ 2001;8(2):171-5. [CrossRef]

19. Moosavi SF, Amirian A, Zarbakhsh B, Kordafshari A, Mirzahoseini $H$, Zeinali $S$, et al. The carrier frequency of a-globin gene triplication in an Iranian population with normal or borderline hematological parameters. Hemoglobin 2011;35(4):323-30. [CrossRef]

20. Guvenc B, Canataroglu A, Unsal C, Yildiz SM, Turhan FT, Bozdogan ST, et al. a-globin chain abnormalities with coexisting a-thalassemia mutations. Arch Med Sci 2012;8(4):644-9. [CrossRef]

21. Farashi S, Bayat N, Faramarzi Garous N, Ashki M, Montajabi Niat M, Vakili $S$, et al. Interaction of an a-globin gene triplication with a-globin gene mutations in Iranian Patients with a-Thalassemia intermedia. Hemoglobin 2015;39(3):2016. [CrossRef]

22. Coelho A, Picanço I, Seuanes F, Seixas MT, Faustino P. Novel large deletions in the human alpha-globin gene cluster: Clarifying the HS-40 long-range regulatory role in the native chromosome environment. Blood Cells Mol Dis 2010;15;45(2):147-53. [CrossRef]

23. Luo S, Chen X, Zhong Q, Wang Q, Xu Z, Qin L, et al. Analysis of rare thalassemia caused by HS-40 regulatory site deletion. Hematology 2020;25(1):286-291. [CrossRef] 
24. Suemasu CN, Kimura EM, Oliveira DM, Bezerra MA, Araújo AS, Costa FF, et al. Characterization of alpha thalassemic genotypes by multiplex ligation-dependent probe amplification in the Brazilian population. Braz J Med Biol Res 2011;44(1):16-22. [CrossRef]
25. Colosimo A, Gatta V, Guida V, Leodori E, Foglietta E, Rinaldi S, et al. Application of MLPA assay to characterize unsolved a-globin gene rearrangements. Blood Cells Mol Dis 2011;15;46(2):139-44. [CrossRef] 